Research

\title{
Analysis and prioritization of risk factors in the management of Halal supply chain management
}

\author{
Adnan Sarwar ${ }^{1} \cdot$ Aqsa Zafar $^{2} \cdot$ Alia Qadir $^{2}$ \\ Received: 23 March 2021 / Accepted: 25 June 2021 \\ Published online: 29 June 2021 \\ (c) The Author(s) $2021 \quad$ OPEN
}

\begin{abstract}
In the competitive globalized market, risk management is an important aspect of the supply chain, but it becomes crucial to the management of a faith-based supply chain. The halal supply chain is an emerging research era at an early stage. To retain the halalness from procurement to end customer, this research was aimed to identify and prioritize the important risk elements for managing the HSC. For this purpose, a literature review was studied, 42 risk factors, classified into seven dimensions, were categorized with the expert's opinion. A fuzzy best-worst method was proposed to analyze and prioritize the risk elements. The results indicated production-related risks are highly significant and sustainability-related risks are the least important among risk elements in the Halal supply chain. This research makes a major contribution by compiling a detailed list of risks associated with Halal supply chain management. It may also assist the manager in mitigations of risks for the Halal supply chain on a priority basis.
\end{abstract}

Keywords Halal supply chain (HSC) $\cdot$ Risk management $\cdot$ Fuzzy best-worst method $\cdot$ Risk assessment

\section{Introduction}

In recent years, risk management has obtained the attention of researchers in various sectors as manufacturing units, healthcare, finance, and supply chain management [1]. The technological shifts, globalization, and innovation in the growing business environment raise the occurrence of risk factors in supply chain management. Globalization and outsourcing practices directly influence the supply chain processes and operations such as operational cost and responsiveness $[2,3]$. Thus, to avoid unfavorable influence on supply chain operations, risk management is considered an essential component of supply chain management [4].

The conventional supply chain and the Halal supply chain (HSC) tolerate certain risks that are necessary to be managed. HSC produces Halal products and delivers to the final customer. The purpose of Halal supply chain management is to assure halal competence. The term halal integrity means the integrity of the material, production processes, and information associated with the products. Particularly, Halal products are considered for beverages, foods, pharmaceuticals, and cosmetics. This variety of products strongly relate to human health and Muslim belief [5]. This is why; various risks that affect the Halal supply chain might harm human health and poor brand image. HSC also faces different types of

Supplementary Information The online version contains supplementary material available at https://doi.org/10.1007/s43621-02100039-6.

Aqsa Zafar, aqsazafarr@gmail.com | 1 Department of Economics and Business Management, University of Veterinary and Animal Sciences, Lahore, Pakistan. ${ }^{2}$ Department of Management Sciences, Riphah International University Faisalabad Campus, Faisalabad, Pakistan. 
disruption, together with risks that relate to halal products $[6,7]$. The attention of Halal supply chain management (HSCM) is to retain the halalness of products from the procurement stage to the consumption stage. To meet these objectives, many risks occur at the different stages of HSC that negatively disrupt the supply chain performance. Furthermore, the stakeholders or organizations might make an effort to cut the risks, to maintain integrity in HSC. Thus, risk management is a crucial part of Halal supply chain management to handle risk.

The literature illustrates several investigations have been conducted on risk management from different perspectives [8]. The conventional supply chain risk management (SCRM) analyzes the supply chain with a conventional supply risk management network. Specifically, the risk management framework deals with food supply chain risks such as food quality and safety [9-11].

Extensive work is being done in the SCRM area to manage and minimize the negative effects of risk development. Risk management with HSCs more crucial due to the problem of lawful integrity, but it is somewhat unexpected that HSCrelated research has received relatively little attention. Similarly, it is important to address the risks associated with HSC and a survey should be conducted to fill this gap in the existing literature. Past studies suggest that approximately all risk management studies have a clear focus on factors related to sustainable development such as sustainable SCRM [12]. All aspects of supply chain risk are considered efficient risk management. Thus, in the sector of halal SCRM, the supply chain and all aspects of the two risks associated with HSC risk are considered effective HSC management. Therefore, the objective of this research is to determine the risks of HSCM. In particular, the main objectives of this study are:

- Examine the present studies to analyze the risks of Halal supply chain management

- Identify major risk factors in Halal supply chain management

- Develop fuzzy BWM methods to prioritize the identified risk factors of the Halal supply chain.

\section{Literature review}

This section provides an understanding of Halal and risk management from the perspective of the Halal supply chain.

\subsection{Halal: a brief introduction}

Halal is a word in the Quran and Arabic that means legal, acceptable, permitted, or lawful. The term halal is associated with food in the Qur'an and Sunnah [13, 14]. The management of a halal food supply chain requires a concerted effort to recognize and increase the major sources of Islam, Sunnah, and the Quran. Halal emphasizes the compliance of Sharia law because it has a broad foundation and should not only target specific demographic beliefs. The Quran verses command every human being to consume halal products. These products are translated as: "O people! Eat of the lawful and pure things in the earth and follow not in the footsteps of Satan (Quran 2:168)."

\subsection{Risk management in halal supply chain}

The term risk has a long history of approximately 2400 years, utilizing the ability of the Athenians to identify and assess risk before making a decision [15]. Today, risk management concepts are being studied from a variety of perspectives, including production, marketing, management, and finance strategy. These various perspectives have different risk understandings. A better understanding of risk is uncertainty about the event [16]. From the management point of view, risk threatens to participate directly intended activity [17].

The literature reports several studies related to risk management from an HSCM perspective. Ali and Suleiman [18] described 6 types of halal integrity risks, including outsourcing/offshore risk, production risk, food-related risk, service risk, raw material risk, and logistics risk. The research also says that these risks may be better managed through supply chain integration. Ujang et al. [19] also identified risks in the halal lean meat supply chain and present strategies to mitigate risks at all stages of beef supply. Tieman [20] introduced a systematic risk prevention cycle for HSCs by mitigating the risks associated with halal integrity. The risk prevention cycle framework incorporates four stages: (re) monitoring, supply chain design, vertical and horizontal collaboration, and risk vulnerability assessment. Wahyuni et al. [21] conducted a study to determine halal risk and food safety in Indonesian chicken products. The study examined two chicken companies to identify key factors and issues of food safety and halal food risk. Haleem [5] analyzed significant risk factors 
associated with the halal food supply chain. They said that the risks associated with raw material integrity and supply are the most important [22].

They reviewed the literature from 1990 to 2018 in the context of food safety and Halal food supply through bibliometrics and network analyses. They found four influential clusters on food safety and two on Halal food. Secinaro et al. [23] examined 221 research articles related to Halal food using the SLR approach. Further, a quantitative method was developed to identify the important bibliometric factors (production process and quality of Halal food). Wahyuni et al. [24], the study proposed the Bayesian Network (BN) structure to identify the risks of Halal food and food safety. The results of this study revealed 19 integrated risks relate to Halal and food safety.

A large number of investigations have been carried out in the area of supply chain management related to risk management, however, research on risk management related to HSC is still in its early stages. This study was conducted to identify risk management from an HSC perspective. Apart from conventional supply chain risks such as planning risks, production risks, and demand risks, HSC includes several other risks that are important to ensure Halal integrity. HSCM's main emphasis is on halal integrity due to the purchasing of diverse raw materials/substances and outsourcing of its diverse operations from different suppliers around the world. The risks related to halal integrity may arise in the differences. And outsourcing diverse operations from different suppliers around the world supply chain stages, such as acid manufacturing, and logistics [25]. The various risks could lead to the production of non-Halal, poor quality, unhygienic consumable goods that could mutilate the brand reputation and influence operational efficiency. Additionally, the rise in risk events like market fluctuations, economic crises, outsourcing/offshoring, terrorism, recession, natural disaster, and wars make matters more complicated.

\section{Methodology}

\subsection{Best worst method}

MCDM methods have been utilized for solving problems in various fields such as supply chains, decision sciences, engineering, and operations in the manufacturing process. The best worst method (BWM) is an MCDM approach proposed by Rezaei [26]. It is an important method to prioritize and select the best and worst among the alternates. To prove the strength of BWM, the author compared BWM statistical results with AHP for the selection of mobile. The results indicated BWM was better than AHP. It becomes popular due to its distinguishing features like least comparisons matrices data required and high consistency among alternatives [27]. The steps of BWM to compute the weights of criteria are given in Appendix A.

\subsection{Identification of risk related to Halal supply chain management}

This study uses Scopus data to recognize major risk elements linked with HSC through a wide range of literature, including sustainable supply chain risk management, and food supply chain risk. To validate the risk elements, a brainstorming session was conducted with the expert's panel. The experts' panel consists of seven members, five experts from the industry that are working in the Halal supply chain located in Pakistan, and two experts from academics. The experts' panel detail is provided in Appendix B.

In the beginning, $72 \mathrm{HSC}$ risks were identified, discussed with the experts, and asked them to finalize the most important risk elements in terms of HSCM. After the expert's opinions, 42 risk factors were selected and The following seven categories are grouped, namely, market-related risks, sustainability-related risks, sourcing-related risks, logistics, and production-related risks, information technology-related risks, outsourcing, and planning related risks. The HSC risk with dimensions is shown in Table 1. The proposed research framework is presented in (Fig. 1).

\subsection{Calculation of risk elements weights}

The decision-making team consisted of seven professionals from industry and academia. The BWM was utilized to calculate the risk factor weights. The BWM procedure is described in Appendix A. The panel of experts was asked to select the best and worst risks from the major risks. Experts were then asked to prioritize the highest risks over other risks and prioritize other risks over the worst. The expert inputs Best-to-Others and Others-to-worst are shown in Tables 2 and 3, respectively. The final weight for each expert is calculated using the procedures in Appendix A. 
Table 1 Risk dimensions related to risk elements of Halal supply chain management

\begin{tabular}{|c|c|c|}
\hline Risk dimensions & Risks elements & References \\
\hline \multirow[t]{5}{*}{ Planning-related risks (PL) } & Risk of policy failure (PL1) & {$[18,28]$} \\
\hline & Lack of management HSC (PL2 & {$[29,30]$} \\
\hline & Intervention by the government and other regulatory agencies (PL3) & {$[31,32]$} \\
\hline & Poor demand forecast (PL4) & {$[32,33]$} \\
\hline & Political instability (PL5) & [34] \\
\hline \multirow[t]{6}{*}{ Sourcing-related risks (SO) } & No halal additives/emulsifiers (SO1) & {$[29,35]$} \\
\hline & Insufficient supply of halal raw material (SO2) suppliers & [18] \\
\hline & Unsanitary of raw materials/components (SO3) & {$[18,36]$} \\
\hline & Information on raw materials/components (SO4) is incomplete & {$[34,37,38]$} \\
\hline & Major supplier (SO5) failure & {$[39,40]$} \\
\hline & Supplier's quality issues (SO6) & {$[32,40,41]$} \\
\hline \multirow[t]{7}{*}{ Production-related risks (PR } & Failure of machinery, equipment, or facilities for producing halal products (PR1) & {$[28,42]$} \\
\hline & Centralized storage of halal and non-halal raw materials and products (PR2 & {$[28,43]$} \\
\hline & General production facility for halal and non-halal products (PR3) & {$[25,43]$} \\
\hline & Halal production lacks skilled/competent/trained workers (PR4) & {$[36,44]$} \\
\hline & Risks in the packaging of halal products (PR5) & {$[34,35]$} \\
\hline & Lack of proper waste disposal/recycling/recycling system (PR6) & [6] \\
\hline & Raw material quality risk (PR7) & [18] \\
\hline \multirow[t]{5}{*}{ Logistic and outsourcing related risks(LO) } & Delivery lead time risk (LO1) & {$[28,45]$} \\
\hline & Pollution risk during storage (LO2) & {$[35,46]$} \\
\hline & Pollution risk during transportation (LO3) & {$[44,47]$} \\
\hline & Outsourcing risks of halal related activities (LO4 & {$[18,28]$} \\
\hline & Perishable risk of halal products (LO5) & {$[18,48]$} \\
\hline \multirow[t]{6}{*}{ Market-related risks (MA) } & Bullwhip effect (MA1) & {$[32]$} \\
\hline & Critical customer failure (MA2) & {$[49,50]$} \\
\hline & Risk of relying on limited customers (MA3) & [51] \\
\hline & Multiple halal certification bodies (MA4) & {$[18,28]$} \\
\hline & Risk of unforgeable labels, such as fake halal logos (MA5) & [18] \\
\hline & Over-reliance on halal certification (MA6) & [18] \\
\hline \multirow[t]{4}{*}{ Information Technology-related risks(IT) } & Information accuracy (IT1) & {$[52,53]$} \\
\hline & Information sharing between SC partners (IT2) & {$[41,54]$} \\
\hline & Information/data integrity (IT3) & {$[55,56]$} \\
\hline & Information flow across HSC (IT4) members & {$[30,36]$} \\
\hline \multirow[t]{9}{*}{ Sustainability-related risks(SU) } & Boycott halal food (SU1) & Expert insight \\
\hline & Social and cultural dissatisfaction with halal (SU2) & Expert insight \\
\hline & Animal welfare/immoral treatment of animals (SU3) & {$[34,36]$} \\
\hline & HSC (SU4) personnel integrity risk & {$[4,55]$} \\
\hline & Risk of strike (SU5) & {$[33,34]$} \\
\hline & Risk of waste discharge (SU6) & [32] \\
\hline & Risks from currency exchange rates (SU7) & {$[42,57]$} \\
\hline & Risks caused by changes in procurement costs (SU8) & {$[30]$} \\
\hline & The high cost of halal raw materials/raw materials (SU9) & [28] \\
\hline
\end{tabular}

Besides, the average weight was considered the final weight to calculate the final weight for the risk category. Table 4 shows the final and average weights of the seven experts. The average $\xi \mathrm{L}$ is 0.09245 (close to zero), demonstrating consistent comparison reliability. 
Fig. 1 Methodological framework for research

\section{Systematic review of literature}

Expert's input

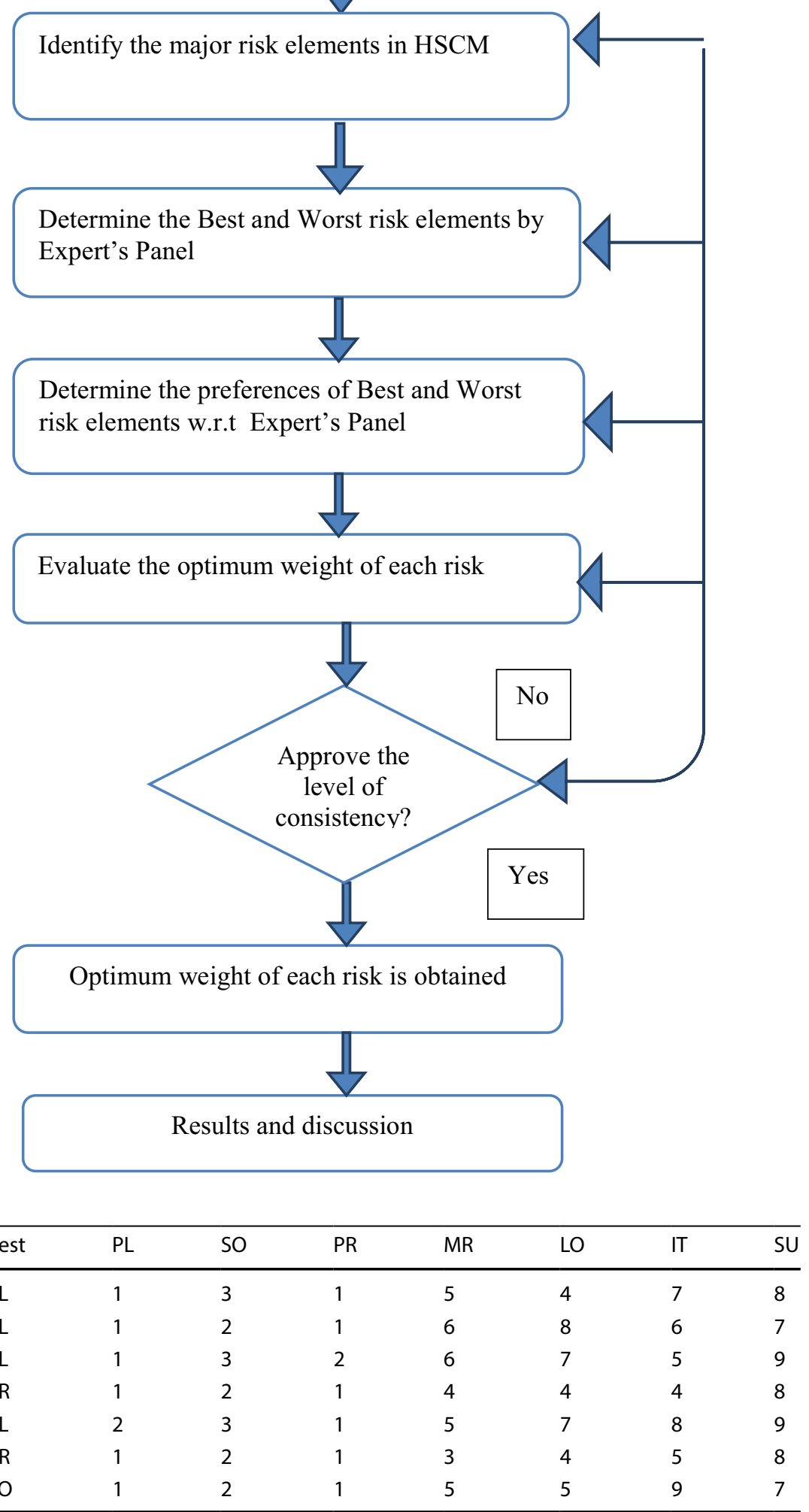

\begin{tabular}{lllllllll}
\hline & Best & $\mathrm{PL}$ & SO & $\mathrm{PR}$ & $\mathrm{MR}$ & LO & IT & SU \\
\hline Expert 1 & $\mathrm{PL}$ & 1 & 3 & 1 & 5 & 4 & 7 & 8 \\
Expert 2 & $\mathrm{PL}$ & 1 & 2 & 1 & 6 & 8 & 6 & 7 \\
Expert 3 & $\mathrm{PL}$ & 1 & 3 & 2 & 6 & 7 & 5 & 9 \\
Expert 4 & $\mathrm{PR}$ & 1 & 2 & 1 & 4 & 4 & 4 & 8 \\
Expert 5 & $\mathrm{PL}$ & 2 & 3 & 1 & 5 & 7 & 8 & 9 \\
Expert 6 & $\mathrm{PR}$ & 1 & 2 & 1 & 3 & 4 & 5 & 8 \\
Expert 7 & $\mathrm{SO}$ & 1 & 2 & 1 & 5 & 5 & 9 & 7 \\
\hline
\end{tabular}


Table 3 Others-to-worst

\begin{tabular}{lllllllll}
\hline & Worst & PL & SO & PR & MR & LO & IT & SU \\
\hline Expert 1 & SU & 8 & 7 & 9 & 2 & 7 & 1 & 1 \\
Expert 2 & IT & 8 & 9 & 5 & 3 & 3 & 2 & 1 \\
Expert 3 & SU & 8 & 6 & 5 & 5 & 5 & 2 & 1 \\
Expert 4 & IT & 7 & 8 & 8 & 7 & 6 & 4 & 1 \\
Expert 5 & SO & 7 & 8 & 9 & 4 & 5 & 2 & 1 \\
Expert 6 & SU & 7 & 9 & 8 & 7 & 6 & 5 & 1 \\
Expert 7 & SU & 9 & 8 & 7 & 4 & 7 & 1 & 1 \\
\hline
\end{tabular}

Table 4 Major risk elements weights

\begin{tabular}{lllllllll}
\hline & $\mathrm{PL}$ & $\mathrm{SO}$ & $\mathrm{PR}$ & $\mathrm{MR}$ & $\mathrm{LO}$ & $\mathrm{IT}$ & $\mathrm{SU}$ & $\xi^{\mathrm{L}}$ \\
\hline Expert 1 & 0.285974 & 0.127099 & 0.340445 & 0.07626 & 0.095325 & 0.027236 & 0.047662 & 0.095325 \\
Expert 2 & 0.319891 & 0.205058 & 0.254272 & 0.068353 & 0.051265 & 0.068353 & 0.032809 & 0.090226 \\
Expert 3 & 0.325463 & 0.140396 & 0.210593 & 0.105297 & 0.105297 & 0.084237 & 0.028717 & 0.095724 \\
Expert 4 & 0.26131 & 0.179407 & 0.284711 & 0.071763 & 0.089704 & 0.089704 & 0.023401 & 0.097504 \\
Expert 5 & 0.230643 & 0.153762 & 0.369028 & 0.092257 & 0.065898 & 0.057661 & 0.030752 & 0.092257 \\
Expert 6 & 0.259303 & 0.167008 & 0.285672 & 0.111339 & 0.083504 & 0.066803 & 0.02637 & 0.074714 \\
Expert 7 & 0.305917 & 0.197643 & 0.257795 & 0.079057 & 0.079057 & 0.024061 & 0.056469 & 0.089369 \\
Final weights & 0.284071 & 0.167196 & 0.286074 & 0.086332 & 0.081436 & 0.059722 & 0.035169 & 0.090731 \\
\hline
\end{tabular}

Similarly, the local and global weights of each risk factor are obtained. The global weights for each dimension under which various risk elements are categorized (Table 5). The weights for each of those risk elements are calculated by the multiplication of associated risk dimensions to the local weight of a particular risk element.

\section{Results and discussion}

The deeper insights of experts, analysis of results are presented in Table 4. The production-related risk holds the highest weight (0.286074) among the other identified risks. The planning-related risk is ranked second with weight (0.284071), source-related risk (0.167193), market-related risk (0.086332), logistics and outsource-related risk (0.081436), information technology-related risk (0.059722), and sustainability-related risk (0.035169). The results suggested that production, planning, and sourcing-related risks as the most obstructive risks in Halal supply chain management.

Production-related risks: Production is the most critical stage in the supply chain, and results showed productionrelated risks are the most significant risks among them. The various risk elements in the production stage enhance the risk in HSC, such as quality of raw material, Halal material storage, and failure of equipment/machinery, etc. Such risks must be tackled on a priority basis to succeed. Planning is the initial part of HSCM, ranked second. The planning-related risks also affected the operations of the supply chain, such as sourcing of raw material, production process, risk of policy failure, poor demand forecasting, lack of commitment to managing HSC, and so on. Thus, such risks need to be considered as greater attention in HSCM.

The most critical risk category in HSCM is source-related risks. It is the initial activity of SC and affects the production and logistics operations. The sourcing-related risk which needs greater attention such as unlawful ingredients, nonhygienic raw material, risk of supplier availability of halal material, and so on. These risks can be removed through the development of multiple sourcing strategies.

Marketing-related risks are also a major risk category of HSCM. It directly influences the organization's brand image and financial losses. The risk of dependency of the limited customer' can be avoided through the development of effective marketing strategies and promoting the characteristics of Halal products. The risk of non-creditable labeling may affect customer trust. It could be reduced by penalizing the organization.

Information technology-related risks are also influenced supply chain activities. The information sharing among the partners of the supply chain may mitigate (information inaccuracy) the trust among partners. So it is significant to adopt effective information technology to eliminate such kind of risk. Mostly, blockchain technology may be adopted in HSCM. 
Table 5 Final ranking of major risk and risk elements of HSC

\begin{tabular}{|c|c|c|c|c|c|c|}
\hline Major risk element & Major weight & Elements code & Local weight & Local rank & Global weight & Global rank \\
\hline \multirow[t]{5}{*}{ Planning-related risks (PL) } & \multirow[t]{5}{*}{0.284071} & (PL1) & 0.393263 & 1 & 0.1117148 & 1 \\
\hline & & $(\mathrm{PL2})$ & 0.153374 & 3 & 0.0435692 & 7 \\
\hline & & (PL3) & 0.092024 & 4 & 0.0261414 & 13 \\
\hline & & (PL4) & 0.325153 & 2 & 0.0923667 & 2 \\
\hline & & (PL5) & 0.036809 & 5 & 0.0104564 & 25 \\
\hline \multirow[t]{6}{*}{ Sourcing-related risks (SO) } & \multirow[t]{6}{*}{0.167196} & (SO1) & 0.421923 & 1 & 0.0705439 & 5 \\
\hline & & (SO2) & 0.169125 & 3 & 0.0282771 & 10 \\
\hline & & (SO3) & 0.197609 & 2 & 0.0330395 & 9 \\
\hline & & (SO4) & 0.037386 & 6 & 0.0062508 & 30 \\
\hline & & (SO5) & 0.101475 & 4 & 0.0169662 & 18 \\
\hline & & (SO6) & 0.072482 & 5 & 0.0121187 & 21 \\
\hline \multirow[t]{7}{*}{ Production-related risks (PR) } & \multirow[t]{7}{*}{0.286074} & (PR1) & 0.306821 & 1 & 0.0877735 & 3 \\
\hline & & (PR2) & 0.164635 & 3 & 0.0470978 & 6 \\
\hline & & (PR3) & 0.070558 & 6 & 0.0201848 & 16 \\
\hline & & (PR4) & 0.246953 & 2 & 0.0706468 & 4 \\
\hline & & (PR5) & 0.098781 & 4 & 0.0282587 & 11 \\
\hline & & (PR6) & 0.029934 & 7 & 0.0085633 & 27 \\
\hline & & (PR7) & 0.082318 & 5 & 0.0235490 & 15 \\
\hline \multirow[t]{5}{*}{ Logistic and outsourcing related risks (LO) } & \multirow[t]{5}{*}{0.081435} & (LO1) & 0.322097 & 1 & 0.0262300 & 12 \\
\hline & & $(\mathrm{LO} 2)$ & 0.127341 & 4 & 0.0103700 & 26 \\
\hline & & (LO3) & 0.302097 & 2 & 0.0246013 & 14 \\
\hline & & (LO4) & 0.191011 & 3 & 0.0155550 & 19 \\
\hline & & (LO5) & 0.037453 & 5 & 0.0030500 & 36 \\
\hline \multirow[t]{6}{*}{ Market-related risks (MA) } & \multirow[t]{6}{*}{0.086332} & (MA1) & 0.136253 & 3 & 0.0117630 & 22 \\
\hline & & (MA2) & 0.059611 & 6 & 0.0051463 & 31 \\
\hline & & (MA3) & 0.400243 & 1 & 0.0345538 & 8 \\
\hline & & (MA4) & 0.170316 & 2 & 0.0147037 & 20 \\
\hline & & (MA5) & 0.136053 & 4 & 0.0117458 & 23 \\
\hline & & (MA6) & 0.097324 & 5 & 0.0084022 & 28 \\
\hline \multirow[t]{4}{*}{ Information Technology-related risks (IT) } & \multirow[t]{4}{*}{0.059722} & (IT1) & 0.020548 & 4 & 0.0012272 & 41 \\
\hline & & (IT2) & 0.118721 & 2 & 0.0070903 & 29 \\
\hline & & (IT3) & 0.296804 & 1 & 0.0177257 & 17 \\
\hline & & (IT4) & 0.063927 & 3 & 0.0038178 & 34 \\
\hline \multirow[t]{9}{*}{ Sustainability-related risks (SU) } & \multirow[t]{9}{*}{0.035169} & (SU1) & 0.138408 & 3 & 0.0048676 & 33 \\
\hline & & (SU2) & 0.083045 & 5 & 0.0029206 & 37 \\
\hline & & (SU3) & 0.141704 & 2 & 0.0049836 & 32 \\
\hline & & (SU4) & 0.103806 & 4 & 0.0036507 & 35 \\
\hline & & (SU5) & 0.026363 & 9 & 0.0009272 & 42 \\
\hline & & (SU6) & 0.051903 & 8 & 0.0018254 & 40 \\
\hline & & (SU7) & 0.326248 & 1 & 0.0114737 & 24 \\
\hline & & (SU8) & 0.059318 & 7 & 0.0020861 & 39 \\
\hline & & (SU9) & 0.069204 & 6 & 0.0024338 & 38 \\
\hline
\end{tabular}

The logistics and outsourcing risks also influenced the supply chain of the organization. Outsourcing of Halal-related activities, delivery lead time, transportation, and warehousing are the significant risks related to logistics and outsourcing. Such risks can be managed and mitigated by proper scheduling of sourcing, production, and storage.

Sustainability is significant for supply chain management. Thus, the risks associated with sustainability are also important in HSCM. Such as production and planning, higher cost for Halal ingredients, these risks can be controlled by effective management. 


\title{
5 Conclusion
}

Risk management is an important aspect of supply chain management. The purpose of this study is to identify and prioritize the risk factors of HSCM. Therefore, for this purpose, 42 risk factors were finalized using systematic literature and expert concerns. Besides, these risks have been categorized into seven key aspects: planning-related risk, procurementrelated risk, production-related risk, logistics, and outsourcing-related risk, market-related risk, information technology, and sustainability-related risk. The fuzzy BWM method is used for more detailed insights to prioritize the final risk factor. After conducting an analysis, this study reveals that the risks associated with production, planning, and procurement are more important than other risks. The global ranking of each risk factor is also obtained based on the weight of their preferences. Finally, based on the analysis, some mitigation strategies are proposed to managers and policy planners.

\section{Research implications}

This research demonstrates that halal supply chain management differs from traditional supply chain management which required specific parameters to meet supply chain objectives. Furthermore, 42 major risks of HSCM were identified that could be applied to the Halal sector specifically the Halal food supply chain, halal cosmetics, etc. This research can assist the managers to develop mitigation strategies to reduce risks in the halal supply chain. It also contributes to the literature of halal supply chain perspective. The identified risk may help the academician to comprehend risks in relevant sectors such as faith-based supply chain and halal food supply chain.

\section{Limitations \& future research}

Similar to other investigations, this research also has some limitations, there are few publications on HSCM. So, some risks related to HSCM may be overlooked. Further, subjective expert opinions can be reduced by using fuzzy set theory, type 2 fuzzy numbers, a grey number which is the advanced version of fuzzy numbers. Future research will develop other MCDM methods, such as analytical network processes (ANP) and prioritization methods based on similarity to ideal situations (TOPSIS), to identify and prioritize risk factors.

\begin{abstract}
Authors' contributions The authors have made a substantial contribution to this article. The conception and design of the study, the analysis, and interpretation were performed by AS and AZ. The critical revision of the article was performed by AQ. All authors have contributed equally to this work. All authors read and provided the final approval of this manuscript.
\end{abstract}

Funding The author(s) received no financial support for the research, authorship, and/or publication of this article.

Data availability The datasets that support the findings of this study are available on request from the corresponding author.

\section{Declarations}

Competing interests The author(s) declared no potential conflicts of interest concerning the research, authorship, and/or publication of this article.

Open Access This article is licensed under a Creative Commons Attribution 4.0 International License, which permits use, sharing, adaptation, distribution and reproduction in any medium or format, as long as you give appropriate credit to the original author(s) and the source, provide a link to the Creative Commons licence, and indicate if changes were made. The images or other third party material in this article are included in the article's Creative Commons licence, unless indicated otherwise in a credit line to the material. If material is not included in the article's Creative Commons licence and your intended use is not permitted by statutory regulation or exceeds the permitted use, you will need to obtain permission directly from the copyright holder. To view a copy of this licence, visit http://creativecommons.org/licenses/by/4.0/.

\section{References}

1. Mangla SK, Kumar P, Barua MK. Risk analysis in green supply chain using fuzzy AHP approach: a case study. Resour Conserv Recycl. 2015;104:375-90.

2. Ganguly K, Kumar G. Supply chain risk assessment: a fuzzy AHP approach. Oper Supply Chain Manag. 2019;12(1):1-13.

3. Niu Z, et al. MicroRNA-21 regulates the self-renewal of mouse spermatogonial stem cells. Proc Natl Acad Sci. 2011;108(31):12740-5. 
4. Christopher M, Lee H. Mitigating supply chain risk through improved confidence. Int J Phys Distrib logist Manag. 2004;34(5):388-96.

5. Haleem A, Khan S, Khan MI. Traceability implementation in food supply chain: a grey-DEMAtel approach. Inf Process Agric. 2019;6(3):335-48.

6. Haleem A, Khan MI. Khan S Conceptualising a framework linking halal supply chain management with sustainability: an India centric study. J Islam Market. 2020. https://doi.org/10.1108/JIMA-07-2019-0149.

7. Khan S, Haleem A, Khan MI, Abidi MH, Al-Ahmari A. Implementing traceability systems in specific supply chain management (SCM) through critical success factors (CSFs). Sustainability. 2018;10(1):204.

8. Baryannis G, Validi S, Dani S, Antoniou G. Supply chain risk management and artificial intelligence: state of the art and future research directions. Int J Prod Res. 2019;57(7):2179-202.

9. Chan HK, Wang X, A Hierarchical Fuzzy TOPSIS Approach for the Risk Assessment of Green Supply Chain Implementation. In: Fuzzy Hierarchical Model for Risk Assessment, Springer, 2013:115-134.

10. Kumar R, Kansara S. Information technology barriers in Indian sugar supply chain: an AHP and fuzzy AHP approach. Benchmarking 2018. https://doi.org/10.1108/BIJ-01-2017-0004.

11. Nakandala D, Lau H, Zhao L. Development of a hybrid fresh food supply chain risk assessment model. Int J Prod Res. 2017;55(14):4180-95.

12. Song $\mathrm{W}, \mathrm{Yu} \mathrm{H}, \mathrm{Xu} \mathrm{H}$. Effects of green human resource management and managerial environmental concern on green innovation. Eur J Innov Manag. 2020;24(3):951-67.

13. Hussaini M. Islamic dietary concepts \& practices. The Islamic Food \& Nutrition Council of America. Carol Stream: Tyndale House Publishers; 1993.

14. Mohamad MH, Future expectations of the halal food industry: Malaysian perspective. 2005.

15. Bernstein PL, Bernstein PL. Against the gods: the remarkable story of risk. New York: Wiley; 1996.

16. Gurnani H, Mehrotra A, Ray S. Supply chain disruptions: Theory and practice of managing risk. Berlin: Springer; 2012.

17. Waters D. Supply chain risk management: vulnerability and resilience in logistics. London: Kogan Page Publishers; 2011.

18. Ali MH, Suleiman N. Eleven shades of food integrity: a halal supply chain perspective. Trends Food Sci Technol. 2018;71:216-24.

19. Ujang M, Mahbubi A, Jie F. Halal risk mitigation in the Australian-Indonesian red meat supply chain. J Islam Mark. 2018;9(1):60-79.

20. Tieman M. Halal risk management: combining robustness and resilience. J Islam Mark. 2017. https://doi.org/10.1108/JIMA-06-2015-0041.

21. Wahyuni HC, Vanany I, Ciptomulyono U, Food Safety and Halal Food Risks in Indonesian Chicken Meat Products: An Exploratory Study, in 2018 IEEE International Conference On Industrial Engineering And Engineering Management (IEEM). 2018: 1011-1015.

22. Wahyuni H, Vanany I, Ciptomulyono U. Food safety and halal food in the supply chain: review and bibliometric analysis. J Indus Eng Manag. 2019;12(2):373-91.

23. Secinaro S, Calandra D. Halal food: structured literature review and research agenda. Br Food J. 2020;123(1):225-43.

24. Wahyuni HC, Vanany I, Ciptomulyono U, Purnomo JDT. Integrated risk to food safety and halal using a Bayesian Network model. Supply Chain Forum An Int J. 2020;21(4):260-73.

25. Khan S, Khan MI, Haleem A, Evaluation of barriers in the adoption of halal certification: a fuzzy DEMAtel approach. J Model Manag. 2019.

26. Liang F, Brunelli M, Rezaei J. Consistency issues in the best worst method: measurements and thresholds. Omega. 2020;96:102175.

27. Najafi NV, Khamseh AA, Mirzazadeh A. An integrated sustainable and flexible supplier evaluation model under uncertainty by game theory and subjective/objective data: Iranian casting industry. Glob J Flex Syst Manag. 2020;21(4):309-22.

28. Khan S, Khan MI, Haleem A, Jami AR. Prioritising the risks in Halal food supply chain: an MCDM approach. J Islam Mark. 2019. https://doi. org/10.1108/JIMA-10-2018-0206.

29. Tan KH, Ali MH, Makhbul ZM, Ismail A. The impact of external integration on halal food integrity. Supply Chain Manag Int J. 2017.

30. Zailani S, Arrifin Z, Abd Wahid N, Othman R, Fernando Y. Halal traceability and halal tracking systems in strengthening halal food supply chain for food industry in Malaysia (a review). J Food Technol. 2010;8(3):74-81.

31. AbTalib MS, Hamid ABA, Chin TA. Motivations and limitations in implementing Halal food certification: a Pareto analysis. Br Food J. 2015;117(11):2664-705.

32. Rostamzadeh R, Ghorabaee MK, Govindan K, Esmaeili A, Nobar HBK. Evaluation of sustainable supply chain risk management using an integrated fuzzy TOPSIS-CRITIC approach. J Clean Prod. 2018;175:651-69.

33. Samvedi A, Jain V, Chan FT. Quantifying risks in a supply chain through integration of fuzzy AHP and fuzzy TOPSIS. Int J Prod Res. 2013;51(8):2433-42.

34. Giannakis M, Papadopoulos T. Supply chain sustainability: a risk management approach. Int J Prod Econ. 2016;171:455-70.

35. Tieman M. The application of Halal in supply chain management: in-depth interviews. J Islam Mark. 2011;2(2):186-95.

36. Khan MI, Haleem A, Khan S. Defining halal supply chain management. Supply Chain Forum Int J. 2018;19(2):122-31.

37. Manning L, Soon JM. Developing systems to control food adulteration. Food Policy. 2014;49:23-32.

38. Soon JM, Chandia M, Mac Regenstein J. Halal integrity in the food supply chain. Br Food J. 2017;119(1):39-51.

39. Ali MH, Tan KH, Makhbul ZM, and Ngah AH, Augmenting halal food integrity through supply chain integration. Jurnal Pengurusan (UKM Journal of Management).2016; 48.

40. Guertler B, Spinler S. Supply risk interrelationships and the derivation of key supply risk indicators. Technol Forecast Soc Chang. 2015;92:224-36.

41. Song W, Ming X, Liu H-C. Identifying critical risk factors of sustainable supply chain management: a rough strength-relation analysis method. J Clean Prod. 2017;143:100-15.

42. Tummala VR, Schoenherr T. An implementation decision framework for supply chain management: a case study. Int J Logist Syst Manag. 2011;8(2):198-213

43. Tieman M, Van der Vorst JG, Ghazali MC. Principles in halal supply chain management. J Islam Mark. 2012;3:217-43.

44. Haleem A, Khan MI. Towards successful adoption of halal logistics and its implications for the stakeholders. Br Food J. 2017;1 19(7):1592-605.

45. Elock Son C, Müller J, Djuatio E. Logistic outsourcing risks management and performance under the mediation of customer service in agribusiness. Supply Chain Forum Int J. 2019;20(4):280-98.

46. Yener D. Factors that affect the attitudes of consumers toward halal-certified products in Turkey. J Food Prod Mark. 2015;21(2):160-78. 
47. Grob K, Biedermann M, Scherbaum E, Roth M, Rieger K. Food contamination with organic materials in perspective: packaging materials as the largest and least controlled source? A view focusing on the European situation. Crit Rev Food Sci Nutr. 2006;46(7):529-35.

48. Sufiyan M, Haleem A, Khan S, Khan MI. Evaluating food supply chain performance using hybrid fuzzy MCDM technique. Sustain Prod Consum. 2019;20:40-57.

49. Ho W, Zheng T, Yildiz H, Talluri S. Supply chain risk management: a literature review. Int J Prod Res. 2015;53(16):5031-69.

50. Khan S, Haleem A, Khan MI. Risk management in Halal supply chain: an integrated fuzzy Delphi and DEMATEL approach. J Model Manag. 2020. https://doi.org/10.1108/jm2-09-2019-0228.

51. Khan MI, Khan S, Haleem A. Using integrated weighted IRP-Fuzzy TISM approach towards evaluation of initiatives to harmonise Halal standards. Benchmark Int J. 2019;26(2):434-51. https://doi.org/10.1108/BIJ-04-2018-0086.

52. Cao S, Bryceson K, Hine D. Improving supply chain risk visibility and communication with a multi-view risk ontology. Supply Chain Forum Int J. 2020;21(1):1-15.

53. Tang O, Musa SN. Identifying risk issues and research advancements in supply chain risk management. Int J Prod Econ. 2011;133(1):25-34.

54. Dubey R, Gunasekaran A, Childe SJ, Papadopoulos T, Helo P. Supplier relationship management for circular economy. Manag Decis. 2019. https://doi.org/10.1108/MD-04-2018-0396.

55. Ali MH, Tan KH, Ismail MD. A supply chain integrity framework for halal food. Br Food J. 2017;119(1):20-38.

56. Fan H, Li G, Sun H, Cheng TCE. An information processing perspective on supply chain risk management: antecedents, mechanism, and consequences. Int J Prod Econ. 2017;2017(185):63-75.

57. Senthil S, Murugananthan K, Ramesh A. Analysis and prioritisation of risks in a reverse logistics network using hybrid multi-criteria decision making methods. J Clean Prod. 2018;179:716-30.

58. Rezaei J. Best-worst multi-criteria decision-making method: some properties and a linear model. Omega. 2016;2015(64):126-30. https:// doi.org/10.1016/j.omega.2015.12.001.

Publisher's Note Springer Nature remains neutral with regard to jurisdictional claims in published maps and institutional affiliations. 